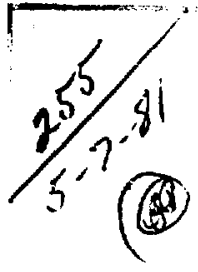

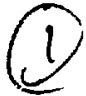

Dr.2611

UCRL-52939

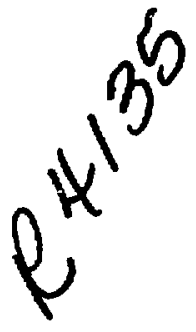

\title{
Spill Exercise 1980: An LLNL Emergency Training Exercise
}

J. L. Morse

T. A. Gibson

W. F. Vance

April 1, 1981 


\title{
Spill Exercise 1980: An LLNL Emergency Training Exercise
}

\author{
J. L. Morse \\ T. A. Gilsom \\ W. F. Vauce
}

Mamucript date: Aprih 1, 1981

\section{LAWRENCE LIVERMORE LABORATORY University of California - Livermore, California - 94550}




\section{CONTENTS}

Abstract. . . . . . . . . . . . . . . . . . . . . . 1

Introduction ................................ 1

Objectives . . . . . . . . . . . . . . . . . . . . . . . . 2

Exercise Control and timitations . . . . . . . . . . . . . . . . 2

Exercise situation ........................... 3

Conclusions and Recomendations . . . . . . . . . . . . . . . . 9

Appendix A. Disaster Exercise Planning Conittee . . . . . . . . . 11

Appendix B. Participants . . . . . . . . . . . . . . . . 12

Append1x c. planning scenario . . . . . . . . . . . . . . 15

Appendix D. Radiation Safety and Health Physics

Subscenar fo and Check11st ................. 19

Appendix E. ARAC Subscenario and Checklist . . . . . . . . . . . 21

Appendix F. Public Information office

Subscenar io and Checklist ................ 28

Appendix G. Control Roon Functions . . . . . . . . . . . . . . . 29

Appendix H. Radiological Safety Evaluation

for spill Exercise $1980 . \ldots 30$

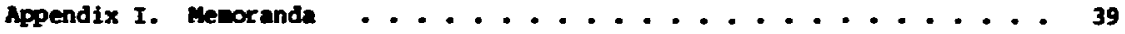


SPILL FXacrge 1980:

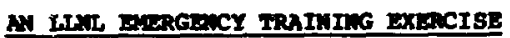

\section{ABSIRACT}

An ewergency training exercise at Lawrence Liverwore National Laboratory (IrsL) demonstated that off-hours energency persornel can respord prontly and effectively to an energency eituation involving radiation, hazardous chemicals, and injured persons. The exercise simulated an explosion in a chenistry labocatory and a subsequent toxic-gas release.

\section{IMTMODUCrIOH}

Periadic training exercises are conducted to ensure that the energency responte perconnel of Lumence Livermore National Laboratory are properly trained to handle energency situations. The first of a new seried of energency training exercien we conducted in Februny 1980. This exercise, entitled apill sxercise 1s80," we plannud, conducted, and controlled by a altidepartental comittee (Appendix $\mathrm{A}$ ).

The exercive alwulated an explosion and radiation epill in a chentetry laboratcry, followed by toxic-gat leak stveral hours later. It was initiated at 5 a.m. On Tueadyy, February 26, and wa sompleted by noon. The exercies we designed to be an realistic as ponsible and to test the general emargey response apability for off-hours ewergencies; sctivitie we 1inited to the che facilleies in Livermore and to the ingediate off-site environent. several apartunts and divisicns participated, including wazard Control, security, Medical, and G-Division (Atmoopheric Release Alisory capability. Mac). The non-linzards control ocganizations wre included begaue they would be inwolved in any real energency of this type. The perticipente are listed in Appendix $B$. 
The objectives of the exercise were to:

- Train and evaluate the performance of apecific IrmL energency responce groups in a sinulated off-hours euergency.

- Test the effectiveness of the Irvi security comunications center and the Itw energency dispatcher (Fire safety Diviaion) in initiating proper commications and procedures to activate the following IIML energency response organizations: Fire Safety Division; Bergency Assistance Tean; Hedical Department; Hazards Control Department's Operational Safety Division, General Safety Division, and Environental Evaluntions Group Off-site Sampling Tzan; and the Adinistration Office.

- Train and exercise Health and Safety Technicians and other personnel in the proper measurement, asserment, and cleanup of a radioactive nuclide spill.

- Test the energency evacuation of in adjecent building (\$-253).

\section{ExacIst Cowmol MD LIMITRTICAs}

An important part of eny emergency exercise is maintaining control of the sequence of events, w that participants are not injured and outeide agencies are not notified needlesuly. Control of Spill Exercise 1940 was providad by vising a detalled scenario (Appendices $C-G$ ) and upire oberration of all activities. A knowledgeable upire was selected fron each group imolved in the exercise to evaluate and control that groug's performance. Dupires were asulgned to locatione from wich they could obeerve the exercice activitien and interect with participants if problem arose. Their prinary responatbility wa to prevent injury or uneceptable exposure of eny participant, uptre, or non-inrolved person. sino actual radionctive nater lale wre ased in the exercise, the upires' second concern wa to prevent the rpread of radiontive material outsid of the inadiate exercise area. Unpirea wre not pirnited to interject gaidance to the participante without firct conferring with the Erercise birector unlen injury. expoesure. be uneceseary contemination would cecur without tinely ection. 
The exercise was held in the Material and Equipment Yard i of B-251 at the Livernore site. Two surplus transport containers were placed in the center of the yard and ataged to resemble a chenistry laboratory. This simulated chenistry laboratory was the focal point of the energency exercise. The sinulated accident was initiated by setting up the laboratory as though a hydrogen explosion had occurred within the laboratory and caused the danage. The result of this explosion vas:

- Physical danage to the laboratory.

- Spillage of several chenical reagent bottles fram their storage shelf onto the laboratory floor. The chenicals were of 10 w toxicity and cleanup presented little hazard.

- Diapersion of radionctive aterial. Actual 1 cu-level ${ }^{223}$ Ra was used within the labocatory, as wes a mult-curie ${ }^{60}$ Co source (see Appendices $B$ and I). Airborne activity was simulated.

- Minor injuries to two experimenters.

A toxic-gas leak was sinulated about 4 hours after the start of the exercise, to test the effectiveness of the evacuation procedures for a nearby building. The leak we sinulated uaing en unlabeled cylinder of carbon dioxide wounted in locked cabinet outside the laboratory. (To prevent discovery and removal of the cylinder before the exercise, a sign was nounted invide che cablnet stating that the cylinder was to be used later in the exercise and should not be disturbed.) At the preacribed tive, the cabinet was unlocked and a label, "Danger: Rheniup/Tungsten Bexafluor ide," was attached to the cylinder. The gylinder valve was opensd, resulting in a sitie pluse of $\mathrm{CO}_{2}$ and inter aroplets. The Disaster Coordinator was imediately handed the aterage:

mis in a exercies. A cylinder of the toxic material sheniug/ Tungsten Iexafluoride has begin leaking. The valve aten is broken betwen the vive and the cylinder. The white woke is the reaction product of the material and air. It is blowing directly toward the air-conditioning intakes of b-253. This is en exercise."

If the Dieaster coordinator had not ordered evecuntion of B-253, he would bare been given a preparad werege reguating evacuakion.

The sctul exqueno of evente at the sinulated eccident ares ouring the exercise me as follows 


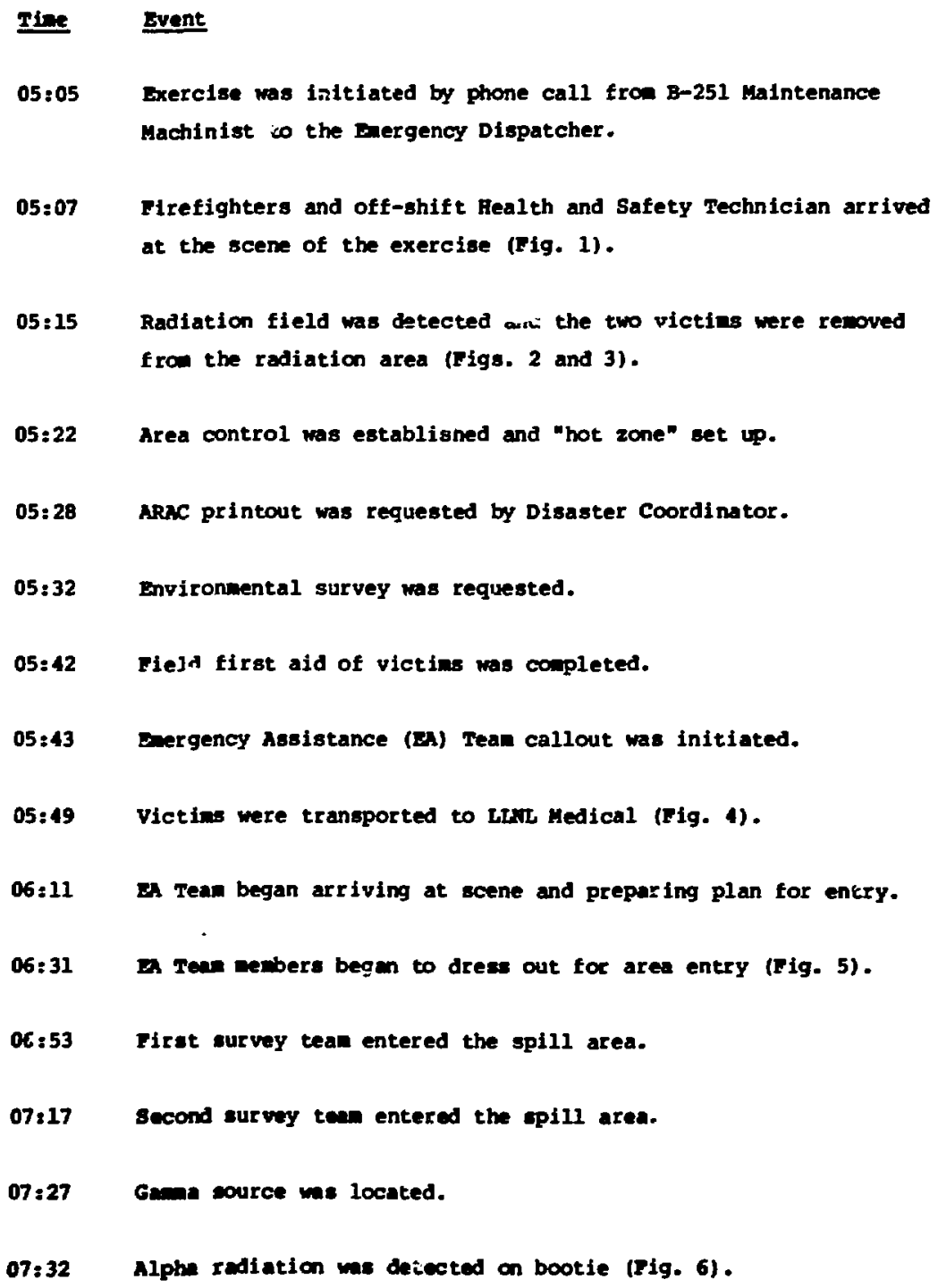

06:11 En Tean began arriving at scene and preparing plan for entry.

06:31 E Tean nembers began to dress out for ares entry (Fig. 5).

oc:53 Firat survey tean entered the spill area.

07.17 second survey tean entered the spill area.

07:27 Gena source me located.

07:32 Alphe radiation we dectected on bootie (Fig. 6). 
PIG. 1. Irdu Fire

Department arrives at the sinulated accident scene 2 vinites after initial call, with one engine company, one abulance, and the comandand-control vehicle.

FIG. 2. Casuslties are exabined for injuries and surveyed for radioactive contanination by off-shift Health and Safety Technician and firenen.

FIG. 3. Unconscious carsulty is removed fra the accident sone.
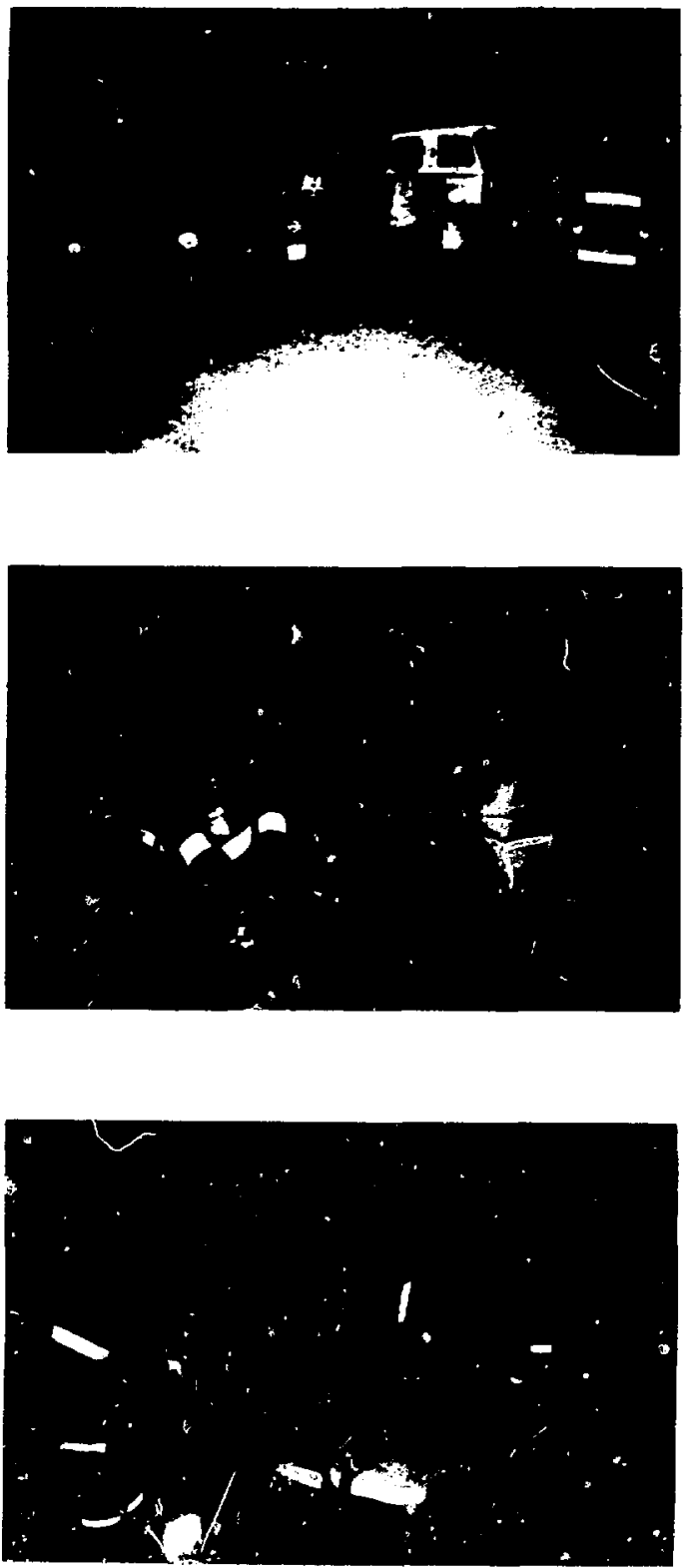


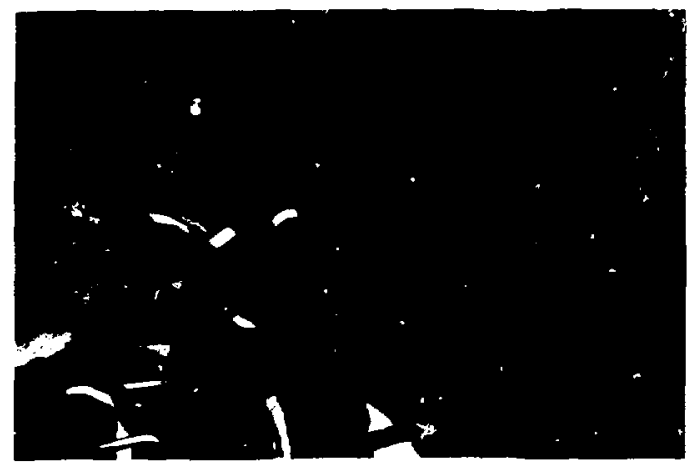

FIG. 4. Casualty in ambulance before transportation to Medical Departiment.

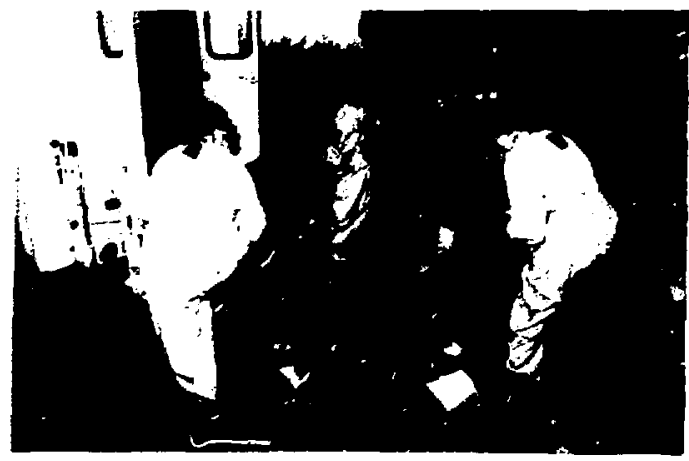

FIG. 5. Energency Assistance rean prepares to enter the accident area.

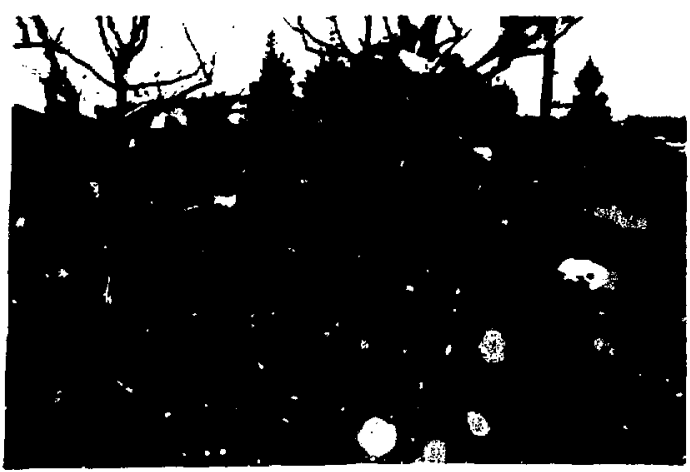

FIG. 6. Individuals exiting the acoident area are monitored at the "hot-line porta1." 


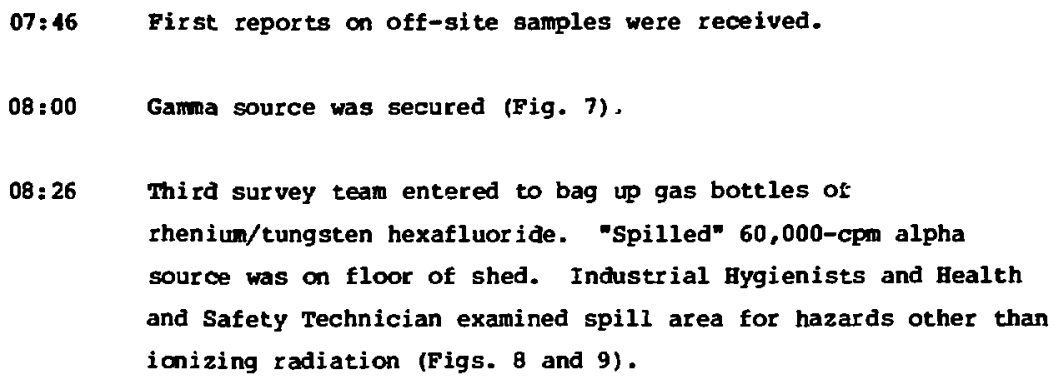

07:46 First reports on off-site samples were received.

08:00 Gamma source was secured (Fig. 7),

08:26 Third survey team entered to bag up gas bottles of rhenium/tungsten hexafluoride. "Spilled" 60,000-cpm alpha source was on floor of shed. Industrial Hygienists and Health and Safety Technician examined spill area for hazards other than ionizing radiation (Figs. 8 and 9 ).

08:55 Team entered in chemical suits to isolate bottles of rhenium/tungsten hexafluoride.

09:05 Simulated hexafluoride leak was initiated (Fig. 10).

09:14 Evacuation of B-251, B-261, and Travel Dept. trailers was simulated. Evacuation of B-253 was initiated (Fig. 11).

09:26 Evacuation ras completed and employees were allowed back into B-253.

09:38 Emergency operations of Spill Exercise 1980 were completed. Remainder of operation was routine radiation spill cleanup and was used to train new Bealth and Safety Technicians.

EIG. 7. ${ }^{60} \mathrm{Co}$ source is removed from the accident area with a rewoce nanipulator, for placenent In a lead pig.

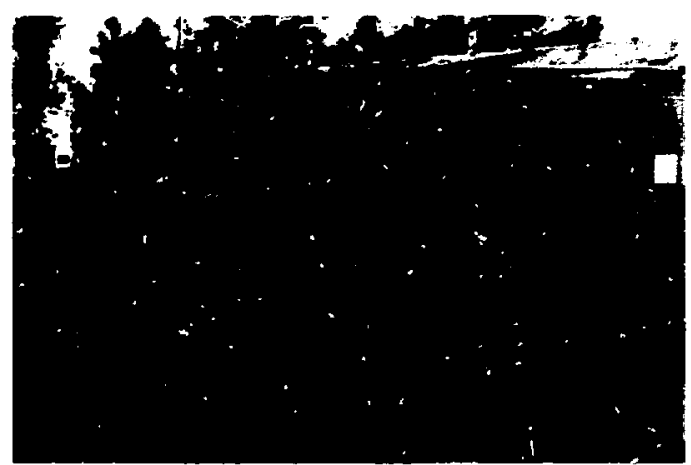




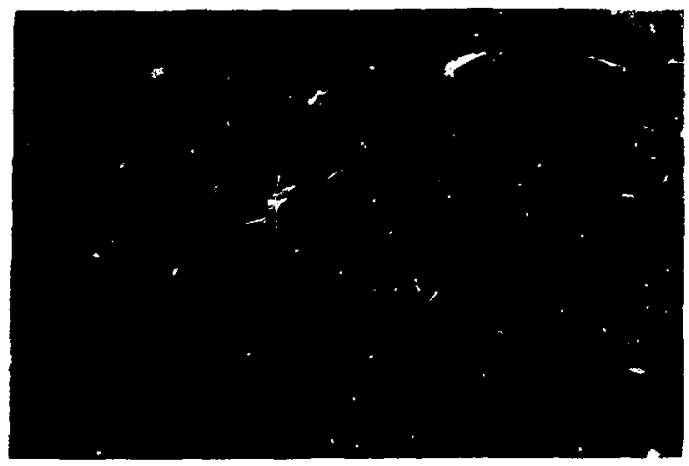

FIG. 8. Industrial

Hygienists and Health and Safety Technicians prepare to enter the accident area.

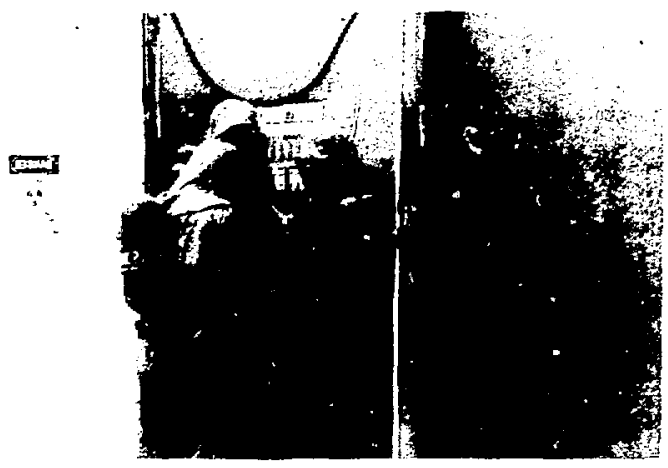

FIG. 9. The accident scene is examined for hazards other than ionization radiation.

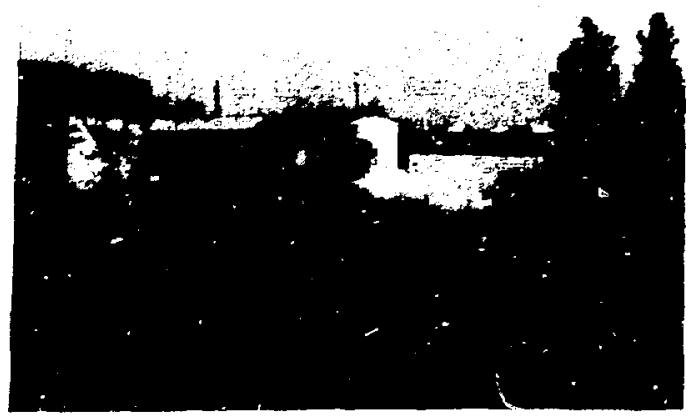

FIG. 10. Simulated release of thenium/tungsten hexafluoride (actually $\mathrm{CO}_{2}$ ). Building 253 is in background. 
FIG. 11. Building 253 is evacuated when the simulated rheniun/tungsten hexafluoride drifts toward its air-conditioning intakes.

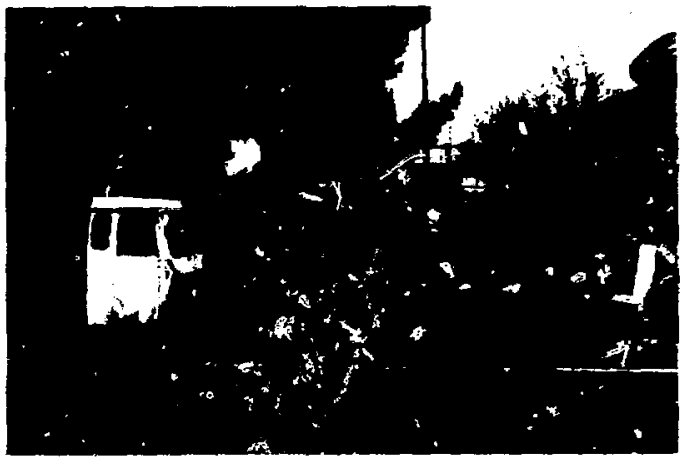

CONCLUSIONS AND RECOMMENDATIONS

Spill Exercise 1980 followed the planned scerario closely. A critique session was held for all participants on February 27. The exercise demonstrated that the Hazards Control Department, as supported by ARAC and Security, can respond promptiy and effectively to an emergency situation involving radiation, hazardous chemicals, and injured personnel during off-hours. The especially favorable aspects of the exercise included:

- Initial size-up by the off-shift Health and Safety Technician and Fire Depar tment.

- Safety Team and Fire Department coordination.

- arac functions.

- Off-site environmental sampling.

- EA Team response and demeanor.

The exercsse also pointed out several areas of needed improvement which should be addressed:

- Improve callout procedures and methods to speed notification of essential personnel. In the exercise, there was unnecessary delay in safety Team Leader, EA Team, and Health and Safety discipline callout. The dispatcher seems to be extremely overloaded during the early stage of an emergency, real or otherwise.

- Improve skil]. and technique in using portable radiation-detection instruments in emergency situations. There was difficulty in locating the 
exact position of the gava source and delay in determining the extent of the alpha contamination. In addition, sall natural thorium sources attached to the victins were not detected because of fallure to use the proper instrunent. - Inprove evacuation procedures for B-253 to include persons outside of the building. During the exercise, an outside contractor with escort was working on the roof and was not evacuated from the area.

- Inprove visitor control at the on-scene co-pand post to eliminate crowding in the area. Spectators without an energency function should be kept clear of the comand poste to prevent unnecessary interference. 


\section{APPENDIX A}

DISASTER EXERCISE PLANNTIG CONITTEE

Chairman: J. L. Morse, Hazards Contrö Department

Nemers: A. L. Buerer, Hazards Control Departnent

T. A. Gibson, Bazards Control Department

G. D. Greenly, G-Division

H. J. Kotowski, Hazards Control Department

J. M. Loverin, Hazards Control Department

2. E. MacBain, Hazards Control Departent

R. T. Trolan, Hazards Control Departaent

W. F. Vance, Hazards Control Departent

G. Y. Liu, Medical Department

J. B. Garberson, Public Information Office*

Homittee involvement for possible or actual press contacts. 
PARTICIPAMTS

\section{Players:}

J. S. Dittig

J. F. Becker

C. W. Mickel

L. A. Chandler

J. F. Corey

G. D. Dakin

J. W. Linhart

T. D. Baird

R. W. Blendow

K. G. Butts

M. P. Lowas

J. c. Mekenzie

M. L. White

D. E. Hankins

K. M. Laudernilch

R. L. Morris

D. S. Myers

J. T. Pawell

R. L. Wilson

J. E. Bardecker

J. R. Poster

J. D. Lun

F. M. Menillen

A. S. Micolosi

R. H. Quast

J. F. Robineon

J. R. Shingleton

w. M. Shea

S. B. Willhoite
Deputy Disaster Director

Safety Tean Leader

Safety Team Leader

Fire Safety, Disaster Coordinator

Fire Safety

Pire Safety

Pire Safety

Fire Services

Fire Services

Fi re Services

Pire Services

Fire Services

Fire Services

Bealth Physics

Bealth Physics

Health Physics

Bealth Physics

Bealth Physics

Bealth Physics

Bealth Safety Technician

Health Safety Technician

Health Safety Technician

Bealth Safety rechnician

Beal th Safety Technician

Bealth Safety Technician

Bealth Safety Technician

Bealth Safety Technician

Health a Safety Technician

Bealth c Safety Technician 

K. C. Young
B. A. Bettencourt
J. S. Johnson
J. Lipera
R. E. Johnson
R. P. Ellis
M. 5. Alton
E. S. Cassaro
R. Iange
L. A. Laweon
R. R. Peterson
D. J. Rodr iguez
C. R. Veith
C. L. Lindeken
H. E. Pfeifer
ฟ. J. silver
A. J. Toy
J. E. White
I. M. Barber
R. J. Davideon
c. . Sunbeck
R. D. Taylor
D. ก. Eoger

Eealth \& Safety Technician, Oul Shift Industrial Hygiene

Industrial Hygiene

Industrial Hygiene

Respirators

Off-site Health \& Safety Technician

ARC, G-Division

ARAC, G-Division

ARAC, G-Division

ARAC, G-Division

ARAC, G-Division

ARC, G-Division

ARAC, G-Division

Environmental Evaluations

Environental Evaluations

Environmental Evaluations

Enviromental Evaluations

Environmental Evaluations

Off-site Sampling Team

Off-site Sampling Tean

Off-site Sampling Tean

Off-site Sapling Tean

Nuclear Chenistry 
J. L. Hor ce

T. A. Gibson

v. F. Vance

J. M. Loverin

R. G. Purington

A. I. Buerer

C. D. Burgin

M. J. Rotowski

R. T. Trolan

H. H. Patterson

H. H. Dickerson

G. D. Greenly

C. B. Ozaki

C. E. Byrne

D. J. Kram
Bazarde Control, Bxercise Director Bealth Physics, Deputy Exercise Director

Control Rocm Operations

Fire Services Operations

Fire Services Operations

Industrial Eygiene

Industrial Safety

Industial Safety

E Tean Operations

Hazaras Control

ARC, G-Division

Arac, G-Division

Bealth Dhyaics

Health $\&$ Safety Technician

Environental bualuations 
APPEADIX C

PLANIIIG BCENARIO

\begin{tabular}{|c|c|c|c|c|}
\hline $\begin{array}{l}\text { Event } \\
\text { No. }\end{array}$ & $\begin{array}{l}\text { Tine } \\
\text { (arprox.) }\end{array}$ & Operation/Event & Ployer oction/Requiremente & $\begin{array}{c}\text { Unplre action, if needed } \\
\text { (real tine) }\end{array}$ \\
\hline 1 & 0500 & $\begin{array}{l}\text { Call to Fo*, explonion } \\
\text { In Rad ochen Bquip yard } \\
\text { (couth of B-253), infuries, } \\
\text { cloud ween roving downind }\end{array}$ & $\begin{array}{l}\text { Fo dispatcher initiater } \\
\text { FD and offehift fics Tech } \\
\text { reaponse (t Security, W, } \\
\text { and Medical) }\end{array}$ & $\begin{array}{l}\text { Give mesiage card to } \\
\text { Dispatcher if action } \\
\text { Incomplete } \\
\text { Make inftial call } \\
\text { in to rD }\end{array}$ \\
\hline 2 & 0505 & Initial aize-up & $\begin{array}{l}\text { 1. Verify telephone report } \\
\text { Injuries } \\
\text { - Rire } \\
\text { Rudiation } \\
\text { 2. Begin gathering info } \\
\text { for action } \\
\text { Witnectes } \\
\text { His Tech } \\
\text { Experimenter } \\
\text { Alr eamples }\end{array}$ & $\begin{array}{l}\text { Give measage card(s) } \\
\text { to reaponding tire } \\
\text { officer if aize-up } \\
\text { not accepcuble }\end{array}$ \\
\hline
\end{tabular}

\footnotetext{
mbbreviations are listed at the end of this table.
} 


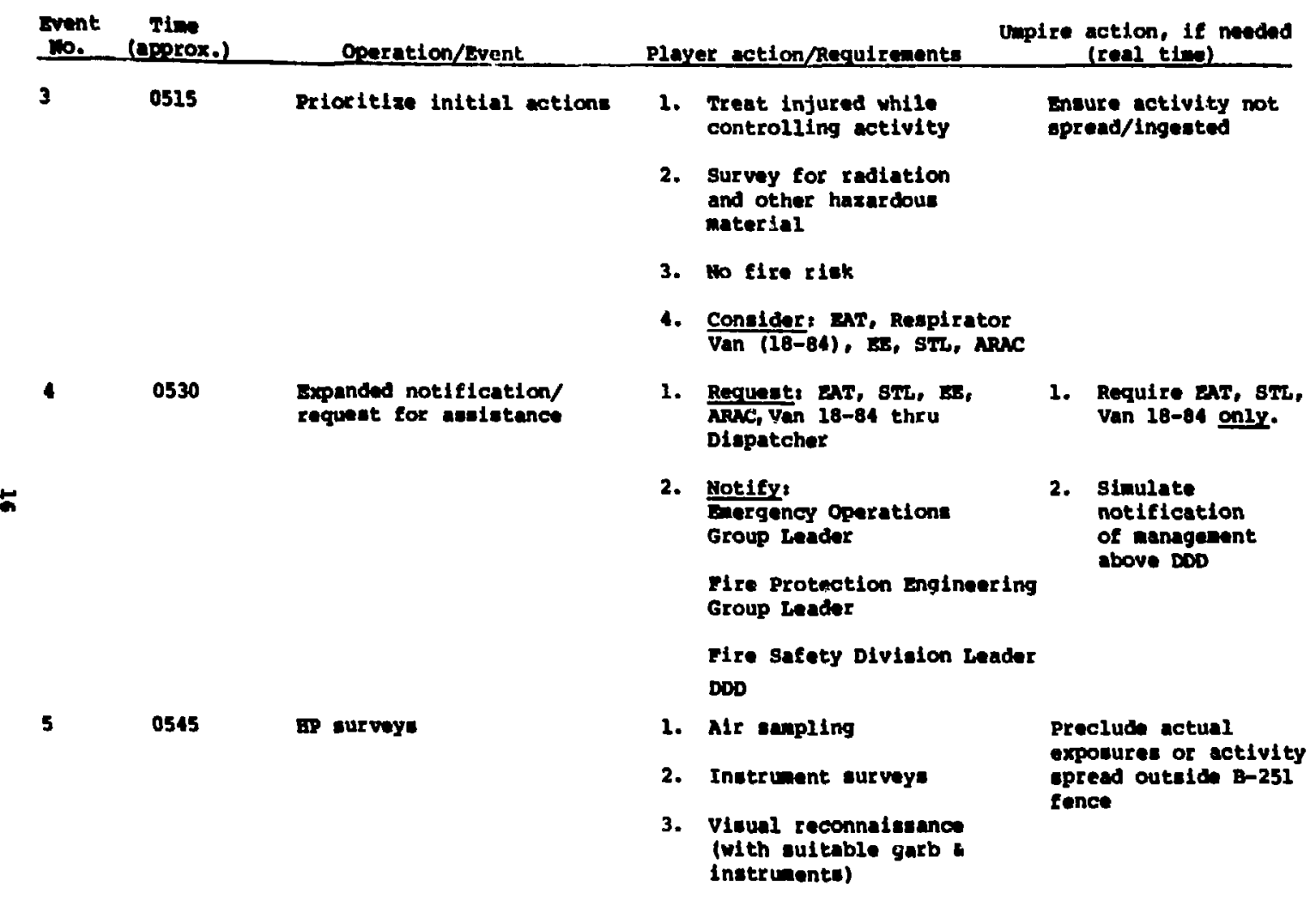




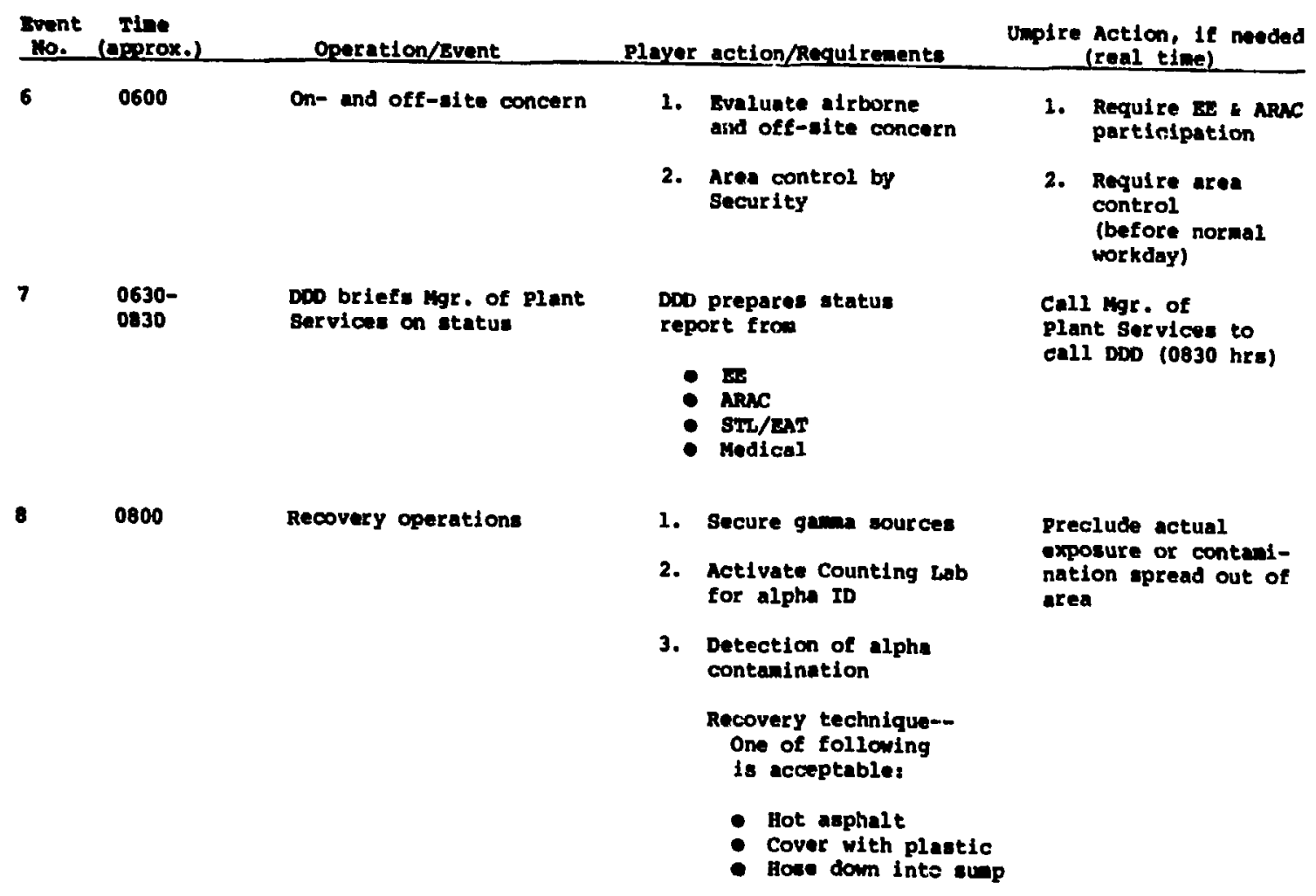




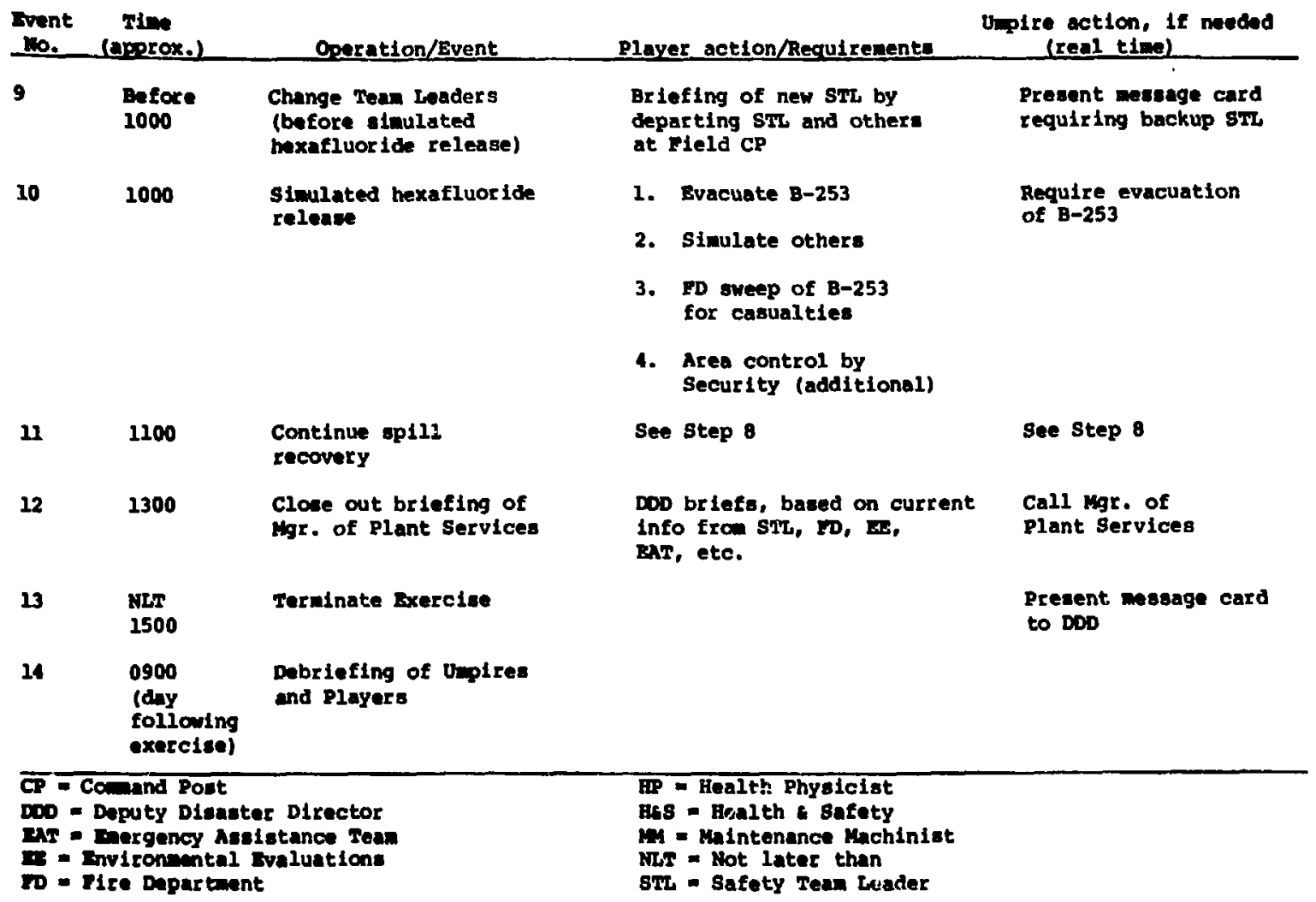




\section{APPEADTX D}

\section{RADIATICA SAFEIY AN HEALIB PHYSICS SUBSCEARTO MD CHECRLIST}

1. Control and Utipire Group will properly post, by signs, area as a radionctive area on the ay before the Exercise.

2. Control and umpire Group will emplace ${ }^{60}$ co source and contaninate exercise location by spraying ${ }^{223} \mathrm{Ra}$ solution on the day before the srercise.

3. Control and buplre Group will ansure that players do the following, if they do not do sane on their om initiative:

a. Establish menned checkpoint for entry to and exit fron area.

b. Provide person aaming Checkpoint with Radiation Incident Iog form.

c. Establish a list of personnel in the area at the time of the incldent. (Make sure that all persons are accounted for.)

d. Establish anned holding area for persono involved in incident.

e. Get briefing on incident from Health and Safety Technician.

f. Does the inclarnt Involve potentially

(1) Elgh radiation fields

(2) High airborse radionctivity level:

(3) Bigh levels of contanination

9. If my memer to $f$ is yes, and for additional Bealth Physics aupport.

h. Prepare to enter area for evaluation.

1. Instruct percon manning holding area to wonitcr personnel wo were in the vicinity of the accident:

(1) Check for external contamination and contaninated sounds

(2) Pull dosineters and send to Personnel Dosinetry

(3) Take nose swabs, as appropriate

j. Segregate exposed perconnel and

(1) send to ridicul (high radiation dose)

(2) Send to Hedical (bioassay) 
(3) Send to Medical (contaninated wound)

(4) Send to wole Body Counter

(5) Send to Decon

k. Establish comunication between health physicist at checkpoint and heilth physicist in aren foc evaluation.

1. Incident Evaluation

(1) size-v?

(2) Start air sapler (fnside and outside area)

(3) Monitor dose rates at specified locations

(4) Evaluate probability of release of radioactive material to environent

(5) Evaluate requirement for additioual afr sampling or monitoring

(6) Mark contaminated and high-radiation areas

(7) Brtef Radiation Safety Division Leader

m. Inform Bealth and Safety Technicien or Erergency Coordinator of requirement for:
(1) Spill Tean
(2) Environmental Survey Tean
(3) Meteorologist

n. Entablish:

(1) Contanination control requireaent

(2) Protective clothing requirements

(3) Reepirator requirement:

(4) Dosimeter requirenents

(5) Linitations on work time in area

(6) Additional ventilation requirement 
APPENDIX E

ARAC SUBSCELARIO ND CHECKLIST

Time

E $+0: 30$

$\mathrm{F}+0: 45$

$\mathbf{H}+1: 00$

H $+1: 30$
Action by participants

Fire Dispatcher alerts MRAC

Central Facility yia ARAC site systen and/or energency call list.

ARAC Central Facility alerts ARAC staff and begins preparation of regional nodel input files. Fire Dispatcher coumunicates to ARAC Central Facility info on energency.

Fire Dispatcher or Off-Site Sapling (OSS) Tean

Captain uses ARAC site system to calcuilate Gaussian $(10-m$ and $40-m$ winds).

ARuc Tean Ieader alerts Conputer Center of "super priority" need and contacts disaster response force leader/Oss Team captain.
Action by umpires, as required

Unpire gives instructions to alert ARh. (Attachment 1). 


\begin{tabular}{|c|c|c|}
\hline B $+2: 40$ & $\begin{array}{l}\text { Regional model calculations made } \\
\text { and contour files sent to LLNL } \\
\text { site for use of disaster } \\
\text { response force and/or oss. }\end{array}$ & \\
\hline & $\begin{array}{l}\text { Fire Dispatcher informs ARAC } \\
\text { Central Facility of new } \\
\text { emergency (leaking cylinder). }\end{array}$ & $\begin{array}{l}\text { Umpire provides winds if needed } \\
\text { and details of leak } \\
\text { (Attachnent } 4 \text { ). Surface winds } \\
\text { are from } 195 \text { degrees at } 2 \mathrm{~m} / \mathrm{s} \text {. }\end{array}$ \\
\hline
\end{tabular}


Attachment No. 1: ARAC Alert Nif: ition

THIS IS AN EXERCISE

YOO ARE TO USE THE ARAC SITE SYSTEM AND ALERT THE ARAC CEATRAL RASILITY TO THE FACT THAT THERE IS AN ENERGEACY EXERCISE IN PROGRESS BY PROVIDING THEY WITH TRE FOLIONTN IMFORHATION:

"THIS IS AN EXERCISE.

ACP THIS IS LLNL WT HAVE AN EXERGENCY IN PROGRESS. AT 13002(0500L) AN EXPLOSTON MA FIRE IN TAE STORAGE YARD OF BIDG. 251 CAUSED A POSSIBLE RELEASE OF TOXIC MATERIAL TO THE ATMOSPHERE. DETAILS UNKNOWN AT THIS TIYE.

THIS IS AN EXERCISE."

THIS IS AN EXEARCISE 
Attachwent No. 2: Information about Exercise Accident

\section{THIS IS AN EXERCISE}

YOU ARE TO USE THE ARNC SITE SYSTEM AND RETAY THE FOILONING INEORMATION ABOUT THIS EXERCISE AOCTDEWT:

"THIS IS AN EXERCISE.

TOXIC CHEAICAL FIRE STARTED 13002, IN STORAGE YATD OF BLDG. 251, FIRE EXTINUISAED AT 13012. ALPEA EVISSIONS DEMECTED. POSSIBLE HEAVY METAL DNOLVED. . POSSIBLY RA-222 AND/OR PU-238."

THIS IS AN EXKRCISE 
Sttachent No. 3: Directive to Use Meteorological Inforention in Exercise

\section{THIS Is an ExERCISE}

YOU ARE TO USE THE AMTACHED MEAEOROLOGICAL INTORATION FOR NY

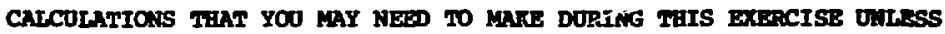

DIRECWED OIHERWISE.

THIS IS AN EEERCISE 
Meteorological Inforeation

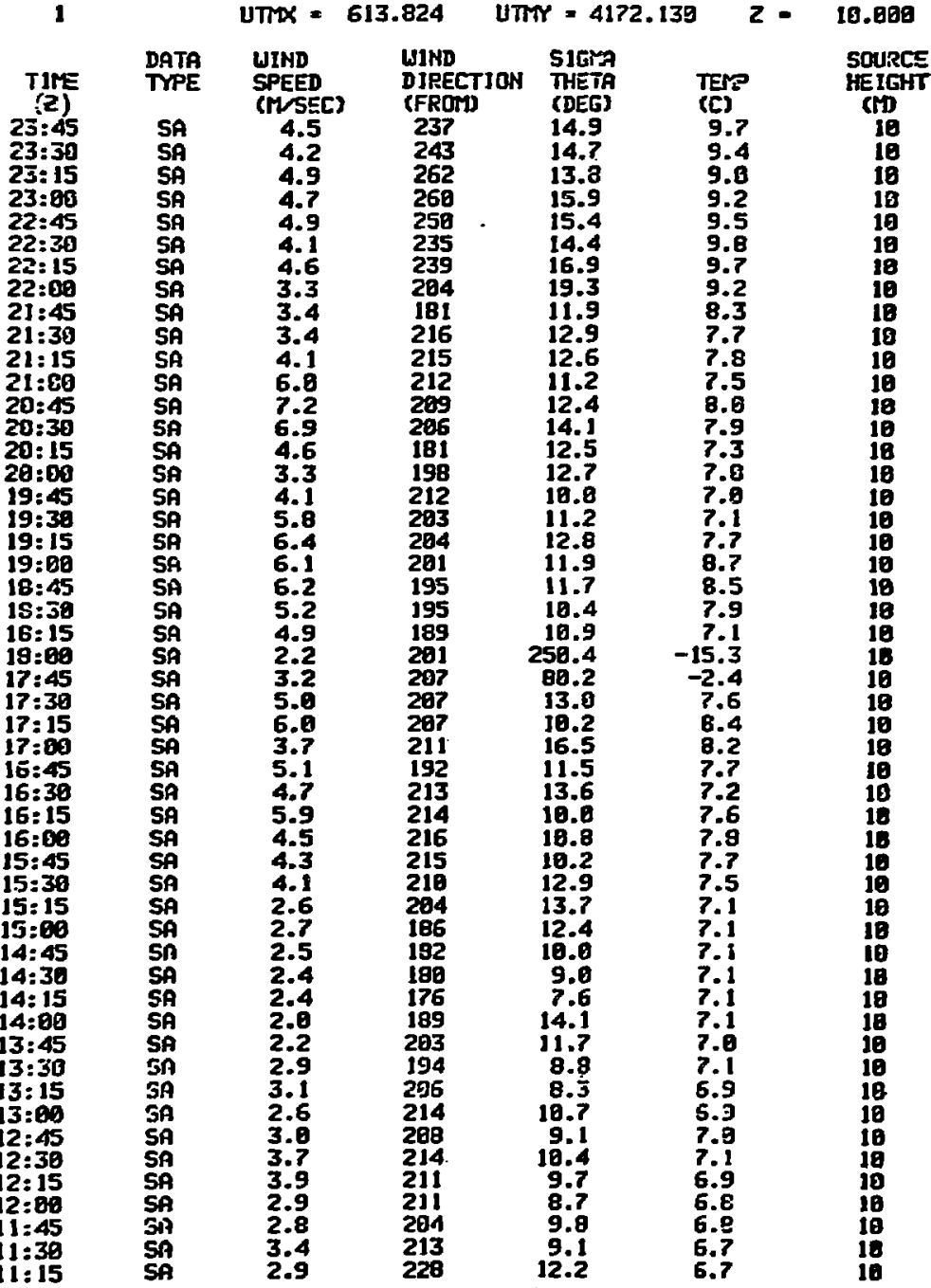


Attachent Ho. 4: Bexafluoride Releage Motification

\section{Iirs Is im Docist}

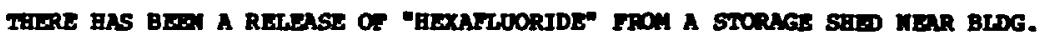
253 ... SURPACE WTIDS ARE From $195^{\circ}$ AT 2.0 nLTERS PAR SECOND. 


\section{APPENDIX $F$}

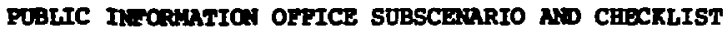

About 1330 hours, Day 1, Garberson phones Public Information office (PIO) playing TV reporter who hears about serious accident on site. fants to filn accident site, bodies, extent of radiation spread, etc.

At about sane tine, Judy Bryer (red-badge pIO engloyee) agpears at South Gate playing rewspaper reporter. She insists on coning on site for interviews at accident scene.

Both Garberson and Bryer will try to get infornation out of non-PIo channels--e.g., from Bazards Control, Plant Managenent, Chenistry, etc.

\section{Tests:}

- PIO ability to get and comunicate accurate, balanced information quickly.

- Cooperation of Hazards control, Pass office personnel, etc., with Pro.

- PIO notification of other comunication outlets (e.g., Vtsitors Center, DOE-SAY PIO). 


\section{APPEDTX G}

\section{cowror Boov Functons}

The control room will serve as headquarters for the control and upire Group. It will be staffed by the sxercise Director and his staff and will be open to all control and unpire Group personnel.

\section{OFERATIOAS}

A. Players will not be allowed into the control room unleas eleared by the Bxercise Director.

B. A log will be kept in witten form indicating the following:

1. Description of operation

2. Tine of inftiation

3. Hethod of initiation (e.g., Dupire, Fire Chief, etc.)

4. Players involved

5. Tine of completion

6. Preliminary grade $(1$ = outstanding, 5 = dreadful)

A tape recorder will be used for verbal backup of the 109 .

c. A statua chart will be kept in brief focin on the blackbourd. This on be used for group briefings.

PaOToenapirc Recom

A. Fotograph: wil be taken by a roving IID photographer. The photographer will bave to be briffed prior to the brexcise.

B. Naditionel photographs wy be taken by control and onple Group personnel.

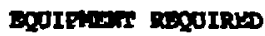
A. Two radios, one for player net and one for control/unptze ret.
B. One telephos and phon book (alwo tazards Control phone 11st).
C. Two tape recordars and extre tupes.
D. 209 book, clipbonrds, pent, pencile, and notepade.
E. Conner and fism. 


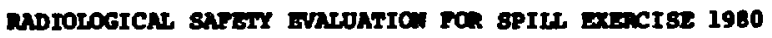

rillian c. xing

nNrootcrion

During the first quarter of 1980, an accident exercise will be conducted at III, Ifvernore site, to train participants and to test the reaponse to a serious accident that results in the epill of radioactive waterials and the releace of chenlcally coxic funes. But the released funes wil not be toxic. A short-lived radionctive naterial will be used.

The simulated accident will occur in two joined trannport conteiners contalning chenical laboratory equigment, such as a glove box and work tables, located outside butlaing 251 on the enst asphalt apron. A liquid containing ${ }^{223} \mathrm{Ra}$ and its dughters will be sprayed into the traneport containere and on the asphelt apron near the door to provide realietic rediation-contuination levels. In adition, a multicurie ${ }^{60}$ co sealed source wil be located inside the tranport containers to provide a high-level gam field. When the response ten arrive at the accident scene, it nust give the ${ }^{60}$ co source inediate attention.

It is desirable to stage this accident exercies at realistically as practicable. Nowerer, to nininise the rediation risk to participants and oberwers and keep the off-aite effecte negligible, the quantities of radiouctive materials used wil make it practically inposible for any one Individul to recelve an mnual radiation internal exposure greater than 0.18 of that pernited under the Pederal Radiation Protection Guides." Thus, the dinietrativ linit of expoure for this exercise, lasting approxinately 8 to $10 \mathrm{~h}$ ouring a single ary, will be established as follows:

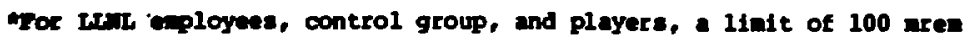
external gawa radiation will be set for the exercise. This liait is wil below the guide line of 3000 nrem per quarter set by Dor regulations and will allow us to use the multicurie ${ }^{60}$ co cource.
} 


\section{Participant off-ite person}

$\begin{array}{lrl}\text { Internal exposure (bone) } & 30 \mathrm{mrem} & 3 \mathrm{mrem} \\ \text { External exposure (whole body) } & 100 \mathrm{mres} & 0.5 \mathrm{mrem}\end{array}$

This report is an evaluation of the radological hazards associated with staging and executing the accident-training splil bxercise 1980.

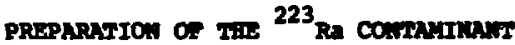

The nuclear Chenistry Division of trer will eupply 0.1 wel ${ }^{223} \mathrm{Ba}$ in solution. The ${ }^{223}$ Ra is prepared from its parent isotopes, ${ }^{227}$ Th and ${ }^{227} \mathrm{AC}$, by chenical separation. The purity of the ${ }^{223}$ Ra colution will be assured to contain lese than $10^{-1} \mathrm{Ci}{ }^{226} \mathrm{Ra},{ }^{227} \mathrm{Th}$, and ${ }^{227} \mathrm{Mc}$ before it will be used in the exercice.

The ${ }^{223}$ Ra wlution will be woved from the nuiclear chenirtry laboratory In vuilding 251 to the aceident site in a leak-tight shielded container. nfter arriving at the aite, it will be diluted with water to approxiantely 2.5 gal In a garden-type sprayer. The eprayer will be uned to dispense tbe solution in the areas to be contminated; about half the colution (50 fri) will be used to contaninate the anphalt surface near the door of the transport containes and the reaninder to contaminate equipaent inside then.

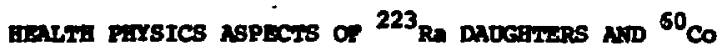

${ }^{223}$ in is an alpha soltter with a half-1ife of $11.43 \mathrm{~d}$. The decay chain of ${ }^{223}$ pa passes through five dunghters to reach stable ${ }^{207} \mathrm{~Pb}$. All the daughters have short half-1ives ranging from 1 = for ${ }^{215}$ po to 36 wly for 211. Alpha, beta, and gama radiations are contted in the decay of the ${ }^{223} \mathrm{ga}$ chain. The ${ }^{223} \mathrm{ga}$ decay chain with the type, energy, and fraction of ench radiation coltted is shom in Fig. H-1. The ganes radiation from a 1-cl point cource of ${ }^{223} \mathrm{R}$ a in equllibriu with ite doughters is $0.12 \mathrm{k} / \mathrm{h}$ at 1 a (Wot. 1$)$.

After dispersal of the 0.1 wel of ${ }^{223}$ na and Its daughters, the direct radiation hesard le minimal potential internal contalnation of the body is a greater risk. 


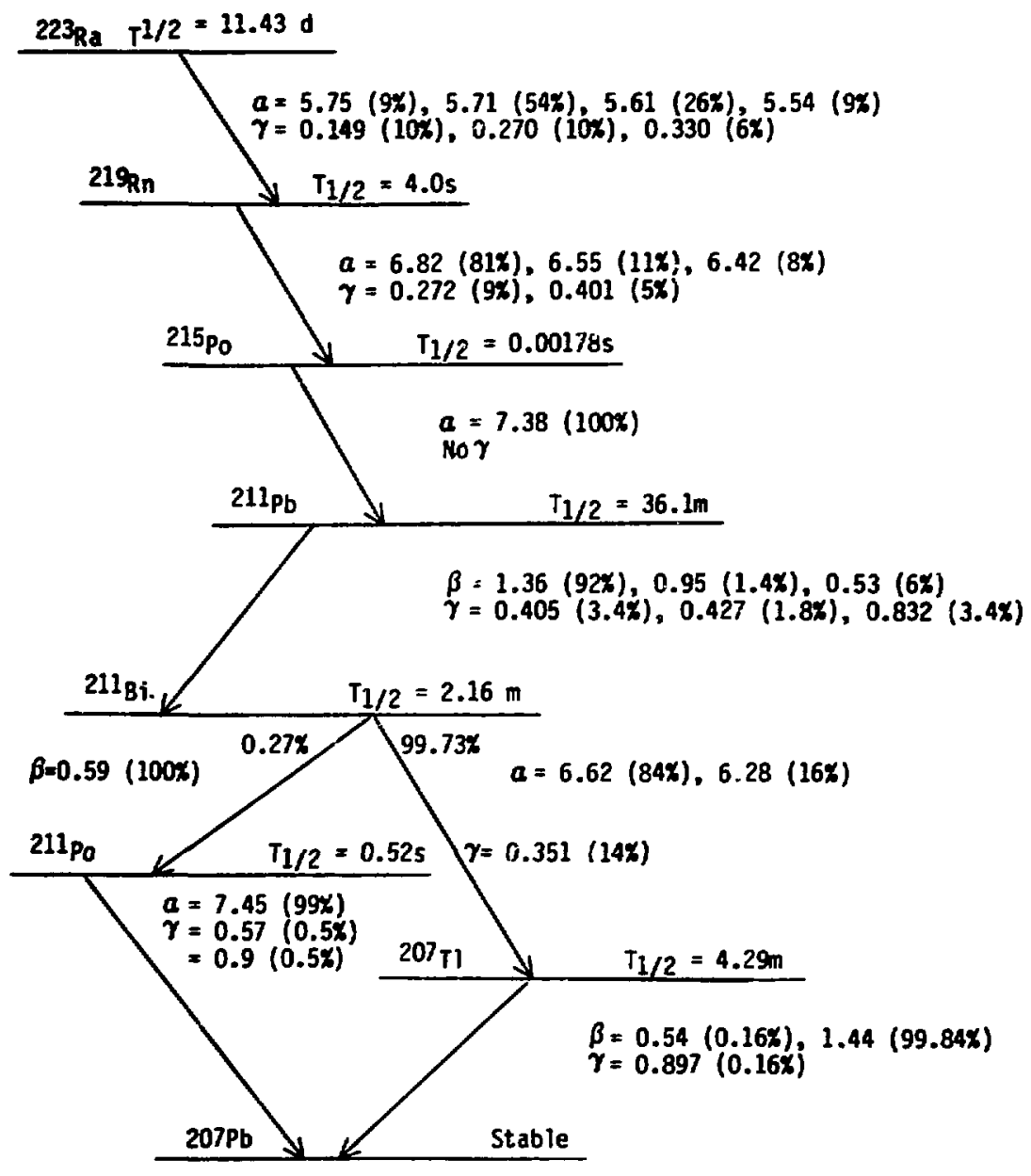

FIG. E-1. The decay chain of ${ }^{223} \mathrm{Ra}$, showing the typea of energy and the frection of exch radiation eitited. For exmple, in " $\alpha=5.75$ (98), the maxim a energy 1. $5.75 \mathrm{MV}$ and 98 of the dialntegratione decay by this nod. 
If ${ }^{223} \mathrm{Rn}$ is taken Into the body efther through inhalation, Ingestion, or through a wound, a fraction of the anterial will translocate fra the Initial ste of aposit to the bone, where it wil reside until it dacay. This wil take several sonths. The annual expoure to the bone peraltt:' under current Foderal Radiation Protection Guides should be no we than 30 realy

In ICRP publication $2,{ }^{2}$ ane finds the following biological data for $223 \mathrm{ra:}$

- Fraction passing from GI tract to blood $=0.3$

- Fraction passing from blood to bone $=0.5$

- Effective half-ilfe of lsotope in bone $=11.4 \mathrm{~d}$

- Total effective energy for the ${ }^{223}$ Ra decay chain $-28.0 \mathrm{kV} / \mathrm{di}$ Integration

- Quilty Factor (QF) = 10

- Mon-uniform distribution fuctor $(n)=1$

Excretion of ${ }^{223} \mathrm{Ra}$ in the urine is given by the equation ${ }^{3}$

$$
0=0.0056(Q \mathrm{BD}) t^{-1.52}
$$

where oBd represents the quantity in the blood an day one and tine (t) is in dys. There ant are uned in the AERIs code to follow the transport of ${ }^{223} \mathrm{Ra}$ to the bane, to anternine the ase to the bone, and to predict the guantity of cotivity in the urine at any time after intake.

Because of the short restience time of ${ }^{223} \mathrm{Ra}$ in the bone, the total Integrated dose fro a ingle Intake is reached within 90 d. That is, the total innul dose to a ingle intake is accumulated in the first guarter-year after Intake.

The wulticurie ${ }^{60} \mathrm{co}$ cource used to give a high $\mathrm{r}$-field will be sealed, wo this will present no internal dose hazard. The health physice aspect of using this wource is the external whole body gama radiation exponure it could produce in the exeicle participants. Two high-energy gana rags are enitted per dieintegration of ${ }^{60} \mathrm{Co}(1.17 \mathrm{KaV}$ and $1.33 \mathrm{kaV})$. The doe rate at $1 \mathrm{~m}$ from $1 \mathrm{Cl}$ of ${ }^{60} \mathrm{Co}$ is $1,2 \mathrm{R} / \mathrm{t}$. The cource uned will not exceed $10 \mathrm{cl}$. 
According to the AERIS Code, a single intake by radiation of $2.5 \mathrm{nCi}$ of ${ }^{223}$ Ra would result in a total integrated dose to the bone of 30 wrem. This is assuning that ${ }^{223} \mathrm{Ra}$ is in a readily soluble form and that the particle size is 1 fa Activity Mean Aerodynamic Dianeter (AND). A single intake by Ingestion of $4.1 \mathrm{nci}$ would result in a total integrated dose to the bone of 30 nren. To linit the inhalation intake to $2.5 \mathrm{nci}$, no personnel will be exposed to an integrated air concentration of greater than $0.12 \mathrm{\mu ci} / \mathrm{min}^{\circ} \mathrm{m}^{-3}$ without respiratory protection. The integrated air concentration outside the Laboratory fence should not exceed one-tenth this value. Fron the cPs code ${ }^{5}$ for IrNI, we find that the reduction in the integrated air concentration between the accident site and $412 \mathrm{~m}$ dowmind (the nearest fence boundary) is $1.4 \times 10^{-3}$ of the source air concentration.

A very sall awount of air activity will be generated during the spraying operation in preparing for the exiscise. The nozzles of the sprayer are designed so that aerosol generation is kept to a very small percentage of the liquid being laid down. The total area initially contaninated on the apron will be 1 ess than $20 \mathrm{~m}^{2}$, and the surface contamination will be linited to $2.5 \mathrm{\mu ci} / \mathrm{m}^{2}$. Therefore, the total anount of surface contanination outside the transport container will be $50 \mathrm{\mu Cl}$ of ${ }^{223} \mathrm{Ra}$. In the Numx-79 operation conducted in April 1979, where these sane sprayers were used to spread the contanination, the amount of aerosol generated was less than 0.012 of the material laid dom. Then this value for aerosol generation is used, the integrated air concentration a few neters downind from the operation is estimated to be 1 ess than $8.3 \times 10^{-5} \mathrm{\mu ci} / \mathrm{min}^{-3} \mathrm{~m}^{-3}$. At the nearest fence 11ne, the integrated concentration will be 1 ess than $1.2 \times 10^{-7} \mathrm{\mu Cl}_{\mathrm{min}} \cdot \mathrm{m}^{-3}$. Once the radiun solution has dried on the asphalt, sone activity in the air could be produced by resuspension of the contaminant. Many factors influence the fraction of waterial resuspended; e.g.. wind velocity over the surface, the wount of traffic disturbance. the length of tive the contaninant has been on the surface, the surface aaterial, and the chenical form of the containant. Wo data exist on resuspension factors for radiu contanination on asphalt pavetuents. Resunpension of plutoniu contanination on soils has been extenstvely studied, however. 6 values have been reported to range from 
$10^{-7}$ to $10^{-3} \mathrm{~m}^{-1}$. If we take the most conservative value as applying to paved asphalt $\left(10^{-3} \mathrm{~m}^{-1}\right)$ then the air concentration observabie from an infinite surface at $2.5 \mu \mathrm{Ci} / \mathrm{m}^{2}$ wold be $2.5 \times 10^{-3} \mu \mathrm{Ci} / \mathrm{m}^{3}$. A working person exposed to this concentration for $B$ h would inhale about $2.5 \mathrm{nCi}$, or the adinistrative linit established for the exercise.

Air concentrations at the fence line will be $3.5 \times 10^{-6} \mathrm{\mu Cl} / \mathrm{m}^{3}$ at the centerline of the plune. These concentrations integrated over $B \mathrm{~h}$ give $0.12 \mu \mathrm{Ci} / \mathrm{min}^{\cdot \mathrm{m}^{-3}}$ at the site and $1.7 \times 10^{-6} \mu \mathrm{Cl} / \mathrm{min}^{-\mathrm{m}^{-3}}$ total integrated exposure concentration.

Part of the practice will be for the accident-response tean to control the spread of contanination. The tea will be zequired to decontaninate or to fix the contanination; therefore, no significant resuspension will occur.

The support staff for the exercise will ensure that air samples are taken on the perimeter of the accident site during the spraying operation and again during the actual exercise. This will docunent the actual air activity generated, and provide data helpful for other exercise planning and for real accidental spills.

Table E-1 sumarizes tire maximum integrated alf activity that might be generated during the exercise. Wo person should exceed the achinistrative linits for inhalation of ${ }^{223} \mathrm{pa}$ curing the exercise. Bowever, for added precaution, personnel who are spraying the contaninant and all participants who enter the contaninated area will wear full-face respiratory equipment and full anti-contanlnation clothing. The ${ }^{223} \mathrm{Ra}$ could be carried outside the boundarles of the accident site through another possible route. If it should rain after the radioactive contanination has been placed on the asphalt apron, the radioactive aterial will be carried awy with the runoff. One reason Building 251 was selected as the eccidant site is that rumoff is to a $60-\mathrm{m}^{3}$ sump, which will prevent the contamination from ruming into the storm sewer. The surface area draining to this ans is $5810 \mathrm{~m}^{2}$ and includes the asphait aprons und the roof area of the building. Therefore, it will take a rainfall of $1.03 \mathrm{~cm}(0.41$ inches) to fill the sus. This wach rainfall is not uncommon for the area during the rainy sauson. However, should the oup fill, a tank truck from Hazards Control Dopartment Maste Diwponal will be ordered in to punp out the water and store it until decay of ${ }^{223}$ Ra is sufficiently 10 to render the liquid haraless. 
TABLE H-1. Maximum integrated air activity that might be generated during the exercise.

\begin{tabular}{|c|c|c|c|}
\hline Location & 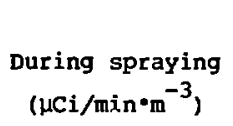 & $\begin{array}{l}\text { Resuspension, } \\
\text { conservative } \\
\left(\mu \mathrm{Ki} / \mathrm{min}^{\bullet} \mathrm{m}^{-3}\right)\end{array}$ & $\begin{array}{l}\text { Administrative } \\
\text { limit } \\
\left(1 \mathrm{Ci} / \mathrm{min}^{\cdot} \mathrm{m}^{-3}\right)\end{array}$ \\
\hline $\begin{array}{l}\text { Accident site } \\
\text { (apron of Bldg. 25l) }\end{array}$ & $8.3 \times 10^{-5}$ & 0.12 & 0.12 \\
\hline $\begin{array}{l}\text { Nearest fence line } \\
\text { (412 } \mathrm{m} \text { west) }\end{array}$ & $1.2 \times 10^{-7}$ & $1.7 \times 10^{-4}$ & $1.2 \times 10^{-2}$ \\
\hline
\end{tabular}

If all $50 \mu \mathrm{Ci}$ of ${ }^{223} \mathrm{Ra}$ should drain into the sump and it fills to $60 \mathrm{~m}^{3}$, the concentration of ${ }^{223} \mathrm{Ra}$ will be $8.3 \times 10^{-7} \mu \mathrm{Ci} / \mathrm{ml}$. A person drinks about $1400 \mathrm{ml}$ of water a day. If the sole source of drinking water for a person was the sump supply, he would ingest $1.2 \times 10^{-3}$ uCi on the first day. This would result in a total integrated exposure to the bone of $8.5 \mathrm{mrem}$. During the exercise and thereafter, the support staff will periodically check the sump. If it approaches the full level, a tank truck will empty the sump and transport the contaminated liquid to the liquid-waste tanks at the decontamination and disposal building on the LLNL site.

The liquid effluent will be held in the sump and in the auxiliary waste tanks (if they are needed) until radioactive decay has reduced the concentration to the level permitted for discharge.

Even if by ovirsight the sump did pump out to the storm sewer during a heavy rain, the radioactivity will be diluted by other runoff so that the concentration would be less than $7 \times 10^{-7} \mu \mathrm{Ci} / \mathrm{ml}$, the Federal Radiation Protection Guide concentration for discharge of ${ }^{223} \mathrm{Ra}$ to an unrestricted area.

If the ${ }^{60} \mathrm{Co}$ source is used, it will pose a potential risk cf external exposure to the players but will have no off-site impact. The exposure rates at various distances from a $10-\mathrm{Ci}{ }^{60} \mathrm{Co}$ source are given in Table $\mathrm{H}-2$. 
TABIE H-2. Exposure rates at various distances from a $10-c i{ }^{60}$ co source.

\begin{tabular}{cc}
\hline Distance $(\mathrm{m})$ & Exposure $(\mathrm{R} / \mathrm{h})$ \\
\hline 0.48 & 127 \\
1 & 11.8 \\
2 & 2.95 \\
5 & 0.47 \\
10 & 0.12 \\
\hline
\end{tabular}

To assure that no player will be exposed above the administrative limit fron this source, umptres will closely monitor the exercise and stop the play if the players do not use proper procecures.

\section{CONCLUSIONS}

The administrative exposure limit for this exercise is set at 0.18 of the maximun annual exposure limit permitted under current radiation protection guides. By limiting the quantity of ${ }^{223} \mathrm{Ra}$ used in the exercise, the calculations made in this paper show that no person should exceed the administrative limit for internal exposure even if his respiratory equipment fails. Cleanup and fixing of the contamination will occur on the day of the exercise so that no residual effects will be present following the exercise. Umpires will observe closely the manner in which the players take care of the ${ }^{60}$ Co source and will stop the play unless the players properly store the source in its shielded container.

This exercise can be conducted safely and will provide sufficient realism to give the accident-response crew excellent training and experience. 
1. W. C. Ring, Radiological Safety Evaluation Report for NWhax-79 Exercise, Lawrence Iivernore National Laboratory, Iivermore, CA, OCr.D-18173 (1979).

2. International Comission on Radiological Protection, "Report of ICreP Comittee II on Pernissible Dose for Internal Radiation (1959) with Bibliography Eor Biological, Mathematical and Physical Data," Bealth Phys. 3 (1960).

3. International Comission on Radiological protection, Report of Comittee IV on Evaluation of Radiation Doses to Body Tissues from Internal Contamination Due to Occupational Exposure, ICRP Publ. 10 (1968).

4. T. J. Powell et al., AERIN--A Computational Version of the ICRP Iung Mode1, Lawrence Iivermore National Laboratory, Iivermore, CA, 0CID-17000 (1976).

5. R. R. Peteson, T. U. Crawford, and I. A. Lawson, CPS: A ContinuousPoint-Source Jomputer Code for Plume Disperson and Deposition Calculations, Lawrence Livermore National Laboratory, Livermore, CA, UCRL-52049 (1976).

6. L. R. Anspaugh et al., "Resuspension and Redistribution of Plutonium in Soils," Health Phys. 29 (1975). 
October 30, 1979

TO: В. พ. Patterson

From: T. A. Gibzon/J. L. Morse

SUBJECT: Briefing Notes and Facts to Support the Use of Radiu-223 (half-life 12 days) for the Spring 1980 "Radiation Spill Exercise"

The Bazards Control Department Spring 1980 exercise has as its principal objective to test and train the energency response organizations of H.t* when they respond to a major spill of radioactive material. The core realistic the exercisez then the better the training, the wore interest show by participants, and the greater the learning and benefit for all personnel involved.

It is proposes to use the radioactive nuclide ${ }^{223} \mathrm{Ra}$ as the contaninant for this exercise. The radiological safety aspects of this alpha enitting nuclide are exhaustively discussed in OCID 18173, "Radiological Safety Evaluation Report for Nomx-79 Bxercise," willian C. King (a copy of wich is attached).

-Organizations that will participate are:

Fire Department Eergency Assistance Tean

Field Tean weader and his field tean Police Departient

off-site sampling Tean

Arac

Public Information office

Deputy Disaster Control Director (or aiternate)

Eurgency Control Coordinator (or alternate) 
It is proposed to use the fenced-in area adjacent to Bldg. 251. This area lies to the east of Bldg. 251, and the fenced area is accessible only through Bldg. 251 and through a gate near the southmest corner of the fenced area. During the exercise, we propose not to enter Bldg. 251, but rather to use only the gate. The water arainage from this area flows north and then west through a grating covered concrete-lined ditch to a retention tank. The total capacity of the tank can be approxinately 50,000 liters (see attached Facility Safety Procedure 251 (Revised June 1, 1979) pages $F-1$ and $F-2$ ).

We propose to place one or two surplus transportainst boxes in the center of the "fenced in area," and then stage these boxes to reserble a chemistry laboratory. The interior of the boxes will be contaninated with ${ }^{223} \mathrm{Ra}$ and this will be the focal point for the exercise. Even if sone of the exercise contaninant should get outside of the transportainer boxes and on the blacktop area, the drainage for the area is such that all of the liquid flor will go to the retention sulp at the northwest corner of Blog. 251. The radioactive contaninant will be dispersed in the sane fashion as it was for the Nown-79 Exercise. No radioactive material will be airborne. This will be achieved by keeping the area suitably dang. Even if it rains during or after the exercise, radiological safety will not be jeopardized because all the surface liguid flow vill go to the retention surg. Total quantities and concentrations of ${ }^{223} \mathrm{Ra}$ used in this exer.:ise will not exceed those used in OCID-18173 to assess potential hazards during konx-79.

The undersigned believe that this radionuclide can be used safely, and that its use will help, in a vital and necessary way, to achieve a good exercise. We night add that a spill exercise without a radioactive nuclide would be marginal at best.

T. A. Gibson

J. I. Morse

PRA:JHagN

Attechnents: UCID-18173

Facility Safety Procedure 251 
Roverber 12, 1979

$\begin{array}{ll}\text { TO: } & \text { V. A. Hode } \\ \text { FROS: } & \text { H. Wade Patterson } \\ \text { SUBJDCT: } & \text { Preparation of }{ }^{223} \text { Ra Sagle }\end{array}$

Recent contact with Nel Coops and Dave Sisson (by Ton Gibsch of Hazards Control) indicate that a sall arount of ${ }^{223} \mathrm{Ra}$ solution could be made up by vuclear chenistry to be used in a spill exercise in the spring of 19a0. I would appreciate your approval to go ahead with the preparation at the proper time. An estinate of your people's Hu' requirenents is also needed. The exast quantity of ${ }^{223} \mathrm{Ra}$ will be determined at a later tine. I would also appreciate your mintaining this preparation in strict confidence.

Thank you for your assistance.

B. Wade Patterson, Departient Fead Hazards Control Departnent

An: $: 9 x$ 
December 14, 1979

TO: N1l Bazards Control Departent Personnel

For: H. Wade Patterson

subJcr: Exercine- 1980

During the firat guarter of 1980 , there will be a major scale disaster exercise at the Livermore aite. This exercise will require the participation of all elements of the Hasards Control Departinent as well. as the participation of other grouge at In-Ifivernore.

This netorandun will be the only announcerent concerning the forthconing exercise.

H. Wade Patterson, Bead

Hazarda Control Departient:

BPaTGeg*

\section{Distribution:}

MII Bnzards control Deprtont Personnel Hasarde control support security Departant - Operations Division

3. D. Garberson, Public Inforeation office

J. B. unox, G-Diviston, for Mnc

D. Z. Wieleen

J. I. Olen 
25141/28795

Jenuary 29, 1900

TO: H. Wade Patterson

Exoy: T. A. Gibeon, Jr./J. L. Morse

stejrct: Update on Planing for Splll bxerciee 1980

Folloring your instructions, a ten-man conittee has been planning the Hazardi Control Departent's ajor exercise for 1980. The undersigned are concerned that the exercise uight be cancelled or postponed because of the recent earthquakes. We believe that a cancellation or postponement (postponewent is tantamount to cancellation) of Spill Ixercise 1980 would not be in the best interests of the Bazards Control Departuent for the following reseone:

- The January 24 and January 26 earthquakes did not produce radioactive spilis of consequence; thus, no experience or training in response to a mojor radioactive epill has occirred. The exercise being planned is strongly oriented toward a spill of radioactive naterial. Our Beslth and Safety Jechnicians and other Bazards Control Departwent personnel still need training in this type of energency lesponte.

- The Muclear Cheristry Division hes granted your Departant peraigsion to use their fenced in area to the east of Bldg. 251 for the exercice. This area is available for use only prior to March 1 , 1980. After then, the area vill not be aveilable until after the upgrade of Bldg. 251 or about June 1981. The fenced in area east of Bldg. 251 is the only truly suitable area on bite for the plenned exercise.

The exercice, unlike reaponse to the recent earthquakes, will be observod and monitored by the Bazards Control Department Bead and his exerciese control and upire group. Correct as vell as incorrect action wili be oberved. Thus, the Bnzards control Department will materially bunefit from the learning experience and entuing critique. 
- The exercies comand and control group extends no higher than the ecting head of Bnzarde Controi Departient on the day of the exercise. Other IrI groups are participating on a voluntary basis. Their participation ia not contral to a successful exercise. Same, uch as PIO and Hedical, will probably not participate.

The undersigned recomend that the exercise planning continue and that the exercies be conducted on one of the planned tive windou daya; 1.e., February 19, 20, 21 or 26, 27, 28.

T. A. Gibson, Jr.

J. L. Morse

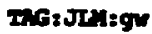


mars is an Ixcrex

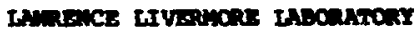

Operational Safety Procedure

Effective: $2 / 19 / 80$

No. 251 Sp $\mathrm{Ex}-\mathrm{e0}$

Expires: $\quad 3 / 19 / 80$

TILE: Bazards Control Department Sp111 Tercige - 1900

INTPODOCTIOA:

Rearon for Istue: to control in a eafe enner an exercige involving and esitting radoactive naterinle and other ateriels.

ResponstetLITIP:S:

Juse L. yorge is responsible for implenenting the controls wet forth in this safety procedare and observance of applicable raboratory safety standards in order to provide for the eafety of chis operation. His alternate is Thones A. Gibeon. Jr.

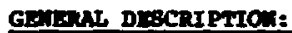

Iocetion: Between BIdg. 255 and Blag. 251

Operations Authorized: All Hazards Control Depertent work and clean up procedures necessary to render the area free from radionctive water ial ind/or orher hasarous naterial.

Enzros malysis: Bigh level gava fields will be present and alpha enitting radiostive nuclides will be gpilled (intentionvily) at the exercise location.

MrenIM Comprs:

On or pore of the following radianctive naterials vill be precent: Co-60, Sr-90, Ir-192, Cm-244, Pu-239, Pr-223, Pb-212, Ra-228

Criticality 8afety: Not apolicable

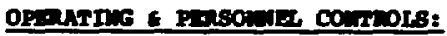

1. All InI Baith and safety Manunl and DOE Manuml Chapters and ocder: will apply and be obeerved. II Disaster Control plan supplenert lo.

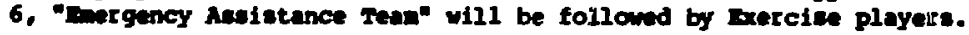

2. Thalological safety Evaluntion for spillex-1sho" by Hillia c. King, Tebruary 1990, will apply this docunent not available to mercies players). 
3. If nocacary, phone the following:

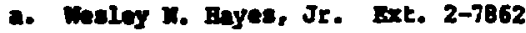

$$
\text { - } \quad: 17-5427
$$

b. Willian E. Eutchin Ext. 2-045:

Bon 582-3646

Dintribution:

$$
\text { RESPCOSIRIS IIDIVIDUNL: }
$$

meroos conrsiol:

ATYEORIZING ITDIVIDUAT:

THIIS IS M ErescIs: 


\section{TRIS IS AN EXPRCISE}

N $\quad$ T I C $\mathbf{E}$

THIS IABORATORY IS UNDER THE COATROL OP:

$$
\begin{aligned}
& \text { WESLEY N. BAYES, JR. } \\
& \text { PBOSE: ORPICE 2-7862 } \\
& \text { EDEE } 447-6427
\end{aligned}
$$

AND

NIFIIN в. HUxcarN

REOIE: GFEICE 2-0451

E0t: 582-3646

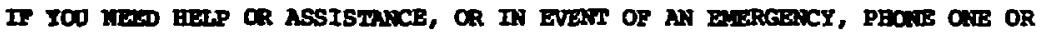
BOtil of Iill ABON.

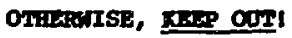

